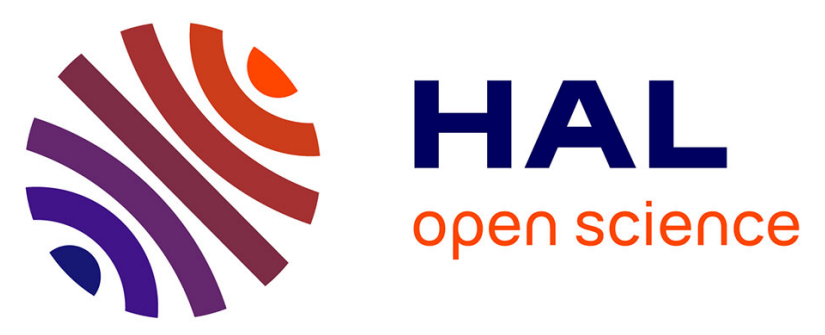

\title{
The odd association of a C3h trisamidinium cation and tosylate anion with a series of linear oxalate-bridged trinuclear heterometallic complexes
}

Catalin Maxim, Emilio Pardo, Mir Wais Hosseini, Sylvie Ferlay, Cyrille Train

\section{- To cite this version:}

Catalin Maxim, Emilio Pardo, Mir Wais Hosseini, Sylvie Ferlay, Cyrille Train. The odd association of a C3h trisamidinium cation and tosylate anion with a series of linear oxalate-bridged trinuclear heterometallic complexes. Dalton Transactions, 2013, 42 (13), pp.4704. 10.1039/C3DT32770A . hal01991213

\section{HAL Id: hal-01991213 \\ https://hal.science/hal-01991213}

Submitted on 24 Nov 2020

HAL is a multi-disciplinary open access archive for the deposit and dissemination of scientific research documents, whether they are published or not. The documents may come from teaching and research institutions in France or abroad, or from public or private research centers.
L'archive ouverte pluridisciplinaire HAL, est destinée au dépôt et à la diffusion de documents scientifiques de niveau recherche, publiés ou non, émanant des établissements d'enseignement et de recherche français ou étrangers, des laboratoires publics ou privés. 


\title{
The odd association of a $\mathrm{C}_{3 \mathrm{~h}}$ trisamidinium cation and tosylate anion with a series of linear oxalate-bridged trinuclear heterometallic complexes
}

\author{
Catalin Maxim, ${ }^{a, b}$ Emilio Pardo, ${ }^{c}$ Mir Wais Hosseini, ${ }^{* d, e}$ Sylvie Ferlay*d,e and Cyrille Train $* a, e, f$ \\ ${ }_{5}$ Received (in XXX, XXX) Xth XXXXXXXXX 20XX, Accepted Xth XXXXXXXXX 20XX \\ DOI: $10.1039 / b 000000 x$
}

A series of six isostructural heterometallic trinuclear oxalate-bridged complexes of formula (TDbenz $)_{2}(\mathrm{TsO})_{2}\left[\mathrm{M}^{\mathrm{II}}\left(\mathrm{H}_{2} \mathrm{O}\right)_{2}\left\{(\mu-\mathrm{ox}) \mathrm{M}^{\mathrm{III}}(\mathrm{ox})_{2}\right\}_{2}\right] \cdot 6 \mathrm{H}_{2} \mathrm{O} \cdot 2 \mathrm{CH}_{3} \mathrm{OH}(\mathrm{TDbenz}=1,3,5$-tris [2-(1,3diazolinium)]benzene; TsO = 4-methylbenzenesulfonate; ox = oxalate; $\mathrm{M}^{\mathrm{III}}=\mathrm{Fe}, \mathrm{M}^{\mathrm{II}}=\mathrm{Mn}(\mathbf{1}), \mathrm{Fe}$ (2), Co $\left.{ }_{10}(3) ; \mathrm{M}^{\mathrm{III}}=\mathrm{Cr}, \mathrm{M}^{\mathrm{II}}=\mathrm{Mn}(4), \mathrm{Fe}(5), \mathrm{Co}(6)\right)$ have been synthesized from $\left(\mathrm{NH}_{4}\right)_{3}\left[\mathrm{M}^{\mathrm{III}}(\mathrm{ox})_{3}\right] \cdot 3 \mathrm{H}_{2} \mathrm{O}$, the chloride salts of the divalent metal ions and the tosylate salt of 1,3,5-tris[2-(1,3-diazolinium)]benzene (trisamidinium). Whereas the crystal structures of compounds 2, 3, 4 and 5 have been investigated by single-crystal X-ray diffraction, the structures of $\mathbf{1}$ and $\mathbf{6}$ have been checked by X-ray powder diffraction. All six compounds are $i$ sostructural and crystallise in the $P \overline{1}$ space group. The crystals are composed of

15 discrete linear $\left[\mathrm{M}^{\mathrm{II}}\left(\mathrm{H}_{2} \mathrm{O}\right)_{2}\left\{(\mu-\mathrm{ox}) \mathrm{M}^{\mathrm{III}}(\mathrm{ox})_{2}\right\}_{2}\right]^{4-}$ trinuclear bimetallic units, trisamidinium and tosylate ions and solvent molecules. The linear trinuclear unit is based on a central trans-diaquametal(II) entity connected to two $\left[\mathrm{M}^{\mathrm{III}}(\mathrm{ox})_{3}\right]^{3-}\left(\mathrm{M}^{\mathrm{III}}=\mathrm{Cr}^{\mathrm{III}}, \mathrm{Fe}^{\mathrm{III}}\right)$ moieties through oxalate bridges. The divalent metal ions, surrounded by six oxygen atoms, adopt a distorted octahedral coordination geometry. The coordination sphere is composed of four oxygen atoms belonging to two oxalate ligands and two trans20 coordinated water molecules. One of the oxalate ions is coordinated to the central metal centre whereas the other two oxalate ligands are non-bridging. In the crystal, intermolecular hydrogen bonds involving oxalate ligands, solvent molecules and the counter-ions form a complex 3D network. Variabletemperature magnetic susceptibility measurements indicate an antiferromagnetic interaction between the iron(III) and the metal(II) ions ( $J=-4.23,-6.73,-8.97 \mathrm{~cm}^{-1}$ for $\mathbf{1}, 2$ and $\mathbf{3}$ respectively) whereas this 25 interaction is ferromagnetic when iron(III) is replaced by chromium(III) $\left(J=+1.21,+2.20,+3.63 \mathrm{~cm}^{-1}\right.$ for 4, 5 and 6 respectively). Moreover, the cobalt(II) derivatives exhibit high $D$ values $\left(D=29.3 \mathrm{~cm}^{-1}\right.$ for 3 and $D=27.4 \mathrm{~cm}^{-1}$ for 6 ).

\section{Introduction}

30 The design and synthesis of polynuclear complexes can be of interest regarding their physical properties, in particular for species containing active bridging ligands able to couple paramagnetic metallic centres. ${ }^{1}$ These species are also of interest since, in addition to the difference in the nature of metal centres, 35 the latter may also differ by their oxidation states. ${ }^{2}$ It is worth noting that by combining various metal cations in different oxidation states with a variety of bridging organic ligands, an infinite number of polynuclear species may be designed and prepared.

40 Although the oxalate dianion belongs to the family of dicarboxylate type ligands, owing to the peculiar disposition of the $\mathrm{O}$ donor atoms, it can behave as a chelate. Thus, in the presence of transition metal cations it offers a unique mode of coordination based on the formation of five-membered rings.
45 Due to its symmetrical nature, the oxalate dianion leads, in the presence of appropriately chosen metallic cations, by polycondensation process, to an infinite variety of metalloorganic assemblies resulting from the bridging of metal centre by the dianion. For the one-to-one combination of octahedral 50 tris(oxalato)metallate anionic complexes $\left(\left[\mathrm{M}_{1}{ }^{\mathrm{I} / \mathrm{III}}\left(\mathrm{C}_{2} \mathrm{O}_{4}\right)_{3}\right]^{3-/ 4-}\right)$ with $\mathrm{M}_{2}{ }^{\mathrm{I} / \mathrm{II}}$ cations, the resulting architectures are anionic in nature. The association of the latter with triply chelated tris(diimine)metal(II) complexes behaving as cationic templates leads to the formation of homo- and hetero-metallic homochiral 55 three dimensional $(10,3)$ type anionic coordination polymers $\left[\mathrm{M}_{1}{ }^{\mathrm{II} / \mathrm{III}} \mathrm{M}_{2}{ }^{\mathrm{I} / \mathrm{II}}\left(\mathrm{C}_{2} \mathrm{O}_{4}\right)\right]_{\mathrm{n}}{ }^{2 \mathrm{n}-/ \mathrm{n}-} \cdot 3$ Otherwise, heterometallic honeycombtype two-dimensional $(6,3)$ networks $\left[\mathrm{M}_{1}{ }^{\mathrm{III}} \mathrm{M}_{2}{ }^{\mathrm{II}}\left(\mathrm{C}_{2} \mathrm{O}_{4}\right)_{3}\right]_{\mathrm{n}}{ }^{\mathrm{n}-}$ incorporating a variety of cationic guests molecules between anionic layers such as spin transition complexes, ${ }^{4}$ paramagnetic ${ }_{60}$ decamethylferrocenium, ${ }^{5}$ organic radical cations, ${ }^{6}$ photochromic molecules, ${ }^{7}$ nonlinear optical (NLO)-active molecules, ${ }^{8}$ organic 
$\pi$-electron donors, ${ }^{9}$ or chiral cations ${ }^{10}$ are obtained.

Concerning discrete oxalate-bridged polynuclear complexes, the majority of bimetallic species were obtained using (oxalato)metal complexes bearing blocking terminal ligands. ${ }^{11}$ ${ }_{5}$ Another possible alternative is a combination of $\left[\mathrm{M}_{1}{ }^{\mathrm{III}}\left(\mathrm{C}_{2} \mathrm{O}_{4}\right)_{3}\right]^{3-}$ and $\left[\mathrm{M}_{2}{ }^{\mathrm{II}}\left(\mathrm{H}_{2} \mathrm{O}\right)_{\mathrm{x}}\right]^{2+}$ with suitable auxiliary cationic and anionic species. However, for this type of approach based on multicomponent systems, the experimental tuning of the crystallisation conditions leading to the polycondensation 10 processes is of prime importance. This has been recently described for a series of bimetallic complexes using a hydrogen bond donor auxiliary cation. ${ }^{12}$ Dealing with trinuclear oxalatebridged species, only few examples based on the use of cationic units such as $\mathrm{TTF}^{13}$, redox-active bipyridinium derivatives ${ }^{14}$, or 15 polar species ${ }^{15}$ have been reported so far.

Here, we report on the preparation of a series of six heterotrinuclear complexes 1-6 composed of two different metal centres in the oxidation states II ( $\mathrm{Mn}, \mathrm{Fe}$ and $\mathrm{Co}$ ) and III ( $\mathrm{Cr}$ and $\mathrm{Fe}$ ) interconnected by oxalate bridging ligands. The latter have 20 been formed in the presence of a trisamidinium cation (TDbenz $^{3+}$ = 1,3,5-tris[2-(1,3-diazolinium)]benzene) and a tosylate anion (4methylbenzenesulfonate) (Scheme1). Their synthesis and structural features are described and their magnetic properties discussed.

\section{${ }_{25}$ Experimental}

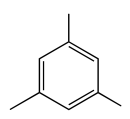

\section{Materials}

Except when mentioned, all chemicals were purchased from commercial sources and were used as received. $\left(\mathrm{NH}_{4}\right)\left[\mathrm{Cr}(\mathrm{ox})_{3}\right] \cdot 3 \mathrm{H}_{2} \mathrm{O}$ was prepared following a reported ${ }_{30}$ procedure $^{16}$ by replacing potassium cations by ammonium moieties. Trisamidinium tosylate were prepared following the literature procedures. ${ }^{17}$ Elemental analyses $(\mathrm{C}, \mathrm{H}, \mathrm{N})$ were performed by the Microanalytical Service of the University of Grenoble.

\section{${ }_{35}$ Synthesis}

Since the experimental procedure used was similar for all six compounds, it is only detailed for the compound $\mathbf{1}$.

(TDbenz $)_{2}(\mathrm{TsO})_{2}\left[\mathrm{Mn}\left(\mathrm{H}_{2} \mathrm{O}\right)_{2}\left\{(\boldsymbol{\mu}-\mathrm{ox}) \mathrm{Fe}(\mathrm{ox})_{2}\right\}_{2}\right] 6 \mathrm{H}_{2} \mathrm{O} 2 \mathrm{CH}_{3} \mathrm{OH}$ (1). $40\left(\mathrm{NH}_{4}\right)_{3}\left[\mathrm{Fe}(\mathrm{ox})_{3}\right] \cdot 3 \mathrm{H}_{2} \mathrm{O}(85.6 \mathrm{mg}, 0.2 \mathrm{mmol})$ and $\mathrm{MnCl}_{2} \cdot 4 \mathrm{H}_{2} \mathrm{O}$ $(19.8 \mathrm{mg}, 0.1 \mathrm{mmol})$ were dissolved in a mixture of water $(2 \mathrm{~mL}$ and methanol $(7 \mathrm{~mL})$. The solution was added to an aqueous solution $(7 \mathrm{~mL})$ of $(\mathrm{TDbenz}) \mathrm{TsO}_{3}(\mathrm{TsO}=$ tosylate $)(160 \mathrm{mg}, 0.2$ mmol), to give a yellow-green solution. Yellow crystals were 45 obtained in $62 \%$ yield after a week upon slow evaporation of the solvents. Elemental analysis calculated (\%) for $\mathrm{C}_{58} \mathrm{H}_{80} \mathrm{MnFe}_{2} \mathrm{~N}_{12} \mathrm{O}_{40} \mathrm{~S}_{2}$ (1816.07): $\mathrm{C}$ 38.35, H 4.44, N 9.25; found: C 38.78, H 4.56, N 9.38; IR: $v=3467(\mathrm{O}-\mathrm{H}), 3134(\mathrm{~N}-\mathrm{H})$, 3045 and $2980(\mathrm{C}-\mathrm{H}), 1703,1662,1650 \mathrm{~cm}^{-1}(\mathrm{C}-\mathrm{O})$.

50

(TDbenz) $)_{2}(\mathrm{TOs})_{2}\left[\mathrm{Fe}\left(\mathrm{H}_{2} \mathrm{O}\right)_{2}\left\{(\boldsymbol{\mu}-\mathrm{ox}) \mathrm{Fe}(\mathrm{ox})_{2}\right\}_{2}\right] 6 \mathrm{H}_{2} \mathrm{O} 2 \mathrm{CH}_{3} \mathrm{OH}$ Using $\mathrm{FeCl}_{2} \cdot 4 \mathrm{H}_{2} \mathrm{O}$ instead of $\mathrm{MnCl}_{2} \cdot 4 \mathrm{H}_{2} \mathrm{O}$ yields $55 \%$ of green crystals of 2. Elemental analysis calculated (\%) for $\mathrm{C}_{58} \mathrm{H}_{80} \mathrm{Fe}_{3} \mathrm{~N}_{12} \mathrm{O}_{40} \mathrm{~S}_{2}$ (1816.97): C 38.33, H 4.43, N 9.25; found: $\mathrm{C}$ ${ }_{55}$ 38.62, H 4.36, N 9.48; IR: $v=3425(\mathrm{O}-\mathrm{H}), 3114(\mathrm{~N}-\mathrm{H}), 3025$ and $2991(\mathrm{C}-\mathrm{H}), 1701,1672,1652 \mathrm{~cm}^{-1}(\mathrm{C}-\mathrm{O})$.

(TDbenz) $)_{2}(\mathrm{TsO})_{2}\left[\mathrm{Co}\left(\mathrm{H}_{2} \mathrm{O}\right)_{2}\left\{(\mu-\mathrm{ox}) \mathrm{Fe}(\mathrm{ox})_{2}\right\}_{2}\right] 6 \mathrm{H}_{2} \mathrm{O} 2 \mathrm{CH}_{3} \mathrm{OH}$ Using $\mathrm{CoCl}_{2} \cdot 6 \mathrm{H}_{2} \mathrm{O}$ instead of $\mathrm{MnCl}_{2} \cdot 4 \mathrm{H}_{2} \mathrm{O}$ yields $75 \%$ of yellow${ }_{60}$ green crystals of 2. Elemental analysis calculated (\%) for $\mathrm{C}_{58} \mathrm{H}_{80} \mathrm{CoFe}_{2} \mathrm{~N}_{12} \mathrm{O}_{40} \mathrm{~S}_{2}$ (1820.06): C 38.27, H 4.43, N 9.23; found: C 38.56, H 4.65, N 9.46; IR: $v=3468(\mathrm{O}-\mathrm{H}), 3129(\mathrm{~N}-\mathrm{H}), 3043$ and $2996(\mathrm{C}-\mathrm{H}), 1701,1656,1643 \mathrm{~cm}^{-1}(\mathrm{C}-\mathrm{O})$.

${ }_{65}$ (TDbenz) ${ }_{2}(\mathrm{TsO})_{2}\left[\mathrm{Mn}\left(\mathrm{H}_{2} \mathrm{O}\right)_{2}\left\{(\boldsymbol{\mu}-\mathrm{ox}) \mathrm{Cr}(\mathbf{o x})_{2}\right\}_{2}\right] 6 \mathrm{H}_{2} \mathrm{O} 2 \mathrm{CH}_{3} \mathrm{OH}$ (4). Using $\left(\mathrm{NH}_{4}\right)_{3}\left[\mathrm{Cr}(\mathrm{ox})_{3}\right] \cdot 3 \mathrm{H}_{2} \mathrm{O}$ instead of $\left(\mathrm{NH}_{4}\right)_{3}\left[\mathrm{Fe}(\mathrm{ox})_{3}\right] \cdot 3 \mathrm{H}_{2} \mathrm{O}$ yields $78 \%$ of violet crystals of 3 . Elemental analysis calculated (\%) for $\mathrm{C}_{58} \mathrm{H}_{80} \mathrm{MnCr}_{2} \mathrm{~N}_{12} \mathrm{O}_{40} \mathrm{~S}_{2}$ (1808.37): C 38.52, H 4.45, N 9.29; found: C 38.86, H 4.52, N 9.58; IR: $v=3477$ (O-H), 3124 $70(\mathrm{~N}-\mathrm{H}), 3035$ and $2981(\mathrm{C}-\mathrm{H}), 1704,1659,1640 \mathrm{~cm}^{-1}(\mathrm{C}-\mathrm{O})$.

(TDbenz) $)_{2}(\mathrm{TsO})_{2}\left[\mathrm{Fe}\left(\mathrm{H}_{2} \mathrm{O}\right)_{2}\left\{(\boldsymbol{\mu}-\mathrm{ox}) \mathrm{Cr}(\mathrm{Ox})_{2}\right\}_{2}\right] 6 \mathrm{H}_{2} \mathrm{O} 2 \mathrm{CH}_{3} \mathrm{OH}$ Using $\mathrm{FeCl}_{2} \cdot 4 \mathrm{H}_{2} \mathrm{O}$ instead of $\mathrm{MnCl}_{2} \cdot 4 \mathrm{H}_{2} \mathrm{O}$ and $\left(\mathrm{NH}_{4}\right)_{3}\left[\mathrm{Cr}(\mathrm{ox})_{3}\right] \cdot 3 \mathrm{H}_{2} \mathrm{O}$ instead of $\left(\mathrm{NH}_{4}\right)_{3}\left[\mathrm{Fe}(\mathrm{ox})_{3}\right] \cdot 3 \mathrm{H}_{2} \mathrm{O}$ yields $7565 \%$ of violet crystals of 5 . Elemental analysis calculated (\%) for $\mathrm{C}_{58} \mathrm{H}_{80} \mathrm{CoCr}_{2} \mathrm{~N}_{12} \mathrm{O}_{40} \mathrm{~S}_{2}$ (1812.37): C 38.43, H 4.44, N 9.27; found: C 38.66, H 4.59, N 9.53; IR: $v=3478(\mathrm{O}-\mathrm{H}), 3126(\mathrm{~N}-\mathrm{H}), 3023$ and $2998(\mathrm{C}-\mathrm{H}), 1703,1646,1623 \mathrm{~cm}^{-1}(\mathrm{C}-\mathrm{O})$.

${ }_{80}$ (TDbenz $)_{2}(\mathrm{TsO})_{2}\left[\mathrm{Co}\left(\mathrm{H}_{2} \mathrm{O}\right)_{2}\left\{(\boldsymbol{\mu}-\mathrm{ox}) \mathrm{Cr}(\mathrm{ox})_{2}\right\}_{2}\right] 6 \mathrm{H}_{2} \mathrm{O} 2 \mathrm{CH}_{3} \mathrm{OH}$ Using $\mathrm{CoCl}_{2} \cdot 6 \mathrm{H}_{2} \mathrm{O}$ instead of $\mathrm{MnCl}_{2} \cdot 4 \mathrm{H}_{2} \mathrm{O}$ and $\left(\mathrm{NH}_{4}\right)_{3}\left[\mathrm{Cr}(\mathrm{ox})_{3}\right] \cdot 3 \mathrm{H}_{2} \mathrm{O}$ instead of $\left(\mathrm{NH}_{4}\right)_{3}\left[\mathrm{Fe}(\mathrm{ox})_{3}\right] \cdot 3 \mathrm{H}_{2} \mathrm{O}$ yields 69 $\%$ of violet crystals of 6 . Elemental analysis calculated (\%) for $\mathrm{C}_{58} \mathrm{H}_{80} \mathrm{FeCr}_{2} \mathrm{~N}_{12} \mathrm{O}_{40} \mathrm{~S}_{2}$ (1809.28): C 38.5, H 4.45, N 9.28; found: ${ }_{85}$ C 38.72, H 4.56, N 9.46; IR: $v=3445(\mathrm{O}-\mathrm{H}), 3214(\mathrm{~N}-\mathrm{H}), 3015$ and $2981(\mathrm{C}-\mathrm{H}), 1704,1662,1653 \mathrm{~cm}^{-1}(\mathrm{C}-\mathrm{O})$.

\section{Physical techniques}

IR spectra of complexes 1 and $2\left(4000-400 \mathrm{~cm}^{-1}\right)$ were recorded with a Bruker IFS55 spectrophotometer ( $\mathrm{KBr}$ pellets).

90 TGA measurements have been performed on Pyris 6 TGA Lab System (Perkin-Elmer), using a $\mathrm{N}_{2}$ flow of $20 \mathrm{~mL} / \mathrm{mn}$ and a heat rate of $4^{\circ} \mathrm{C} / \mathrm{mn}$.

Powder X-ray diffraction (PXRD) diagrams were collected on a Bruker D8 diffractometer using monochromatic $\mathrm{Cu}-\mathrm{K} \alpha$ 95 radiation with a scanning range between $3.8^{\circ}$ and $30^{\circ}$ using a scan step rate of $2^{\circ} \mathrm{mn}^{-1}$.

Magnetic measurements were carried out on powdered samples of 1-6 with a Quantum Design SQUID magnetometer.

Variable-temperature $(1.8-300 \mathrm{~K})$ direct current magnetic 100 susceptibility (dc) was measured under applied magnetic fields of $1 \mathrm{~T}(T>50 \mathrm{~K})$ and $0.025 \mathrm{~T}(T \leq 50 \mathrm{~K})$. The susceptibility data 


\begin{tabular}{|c|c|c|c|c|}
\hline Compound & 2 & 3 & 4 & 5 \\
\hline Chemical formula & $\mathrm{C}_{29} \mathrm{H}_{36} \mathrm{Fe}_{1.5} \mathrm{~N}_{6} \mathrm{O}_{20} \mathrm{~S}$ & $\mathrm{C}_{29} \mathrm{H}_{38} \mathrm{Co}_{0.5} \mathrm{FeN}_{6} \mathrm{O}_{20} \mathrm{~S}$ & $\mathrm{C}_{29} \mathrm{H}_{38} \mathrm{CrMn}_{0.5} \mathrm{~N}_{6} \mathrm{O}_{20} \mathrm{~S}$ & $\mathrm{C}_{29} \mathrm{H}_{38} \mathrm{CrFe}_{0.5} \mathrm{~N}_{6} \mathrm{O}_{20} \mathrm{~S}$ \\
\hline$M\left(\mathrm{~g} \mathrm{~mol}^{-1}\right)$ & 904.47 & 908.03 & 902.18 & 902.64 \\
\hline Temperature, $(\mathrm{K})$ & $150(2)$ & $293(2)$ & $173(2)$ & $173(2)$ \\
\hline Wavelength, $(\AA)$ & 0.5608 & 0.5608 & 0.5608 & 0.71073 \\
\hline Crystal system & triclinic & triclinic & triclinic & triclinic \\
\hline Space group & $P-1$ & $P-1$ & $P-1$ & $P-1$ \\
\hline$a(\AA)$ & $8.7415(11)$ & $8.8522(9)$ & $8.7134(2)$ & $8.7301(2)$ \\
\hline$b(\AA)$ & $15.2796(9)$ & $15.2760(8)$ & $15.3318(3)$ & $15.2924(4)$ \\
\hline$c(\AA)$ & $15.5035(16)$ & $15.5174(12)$ & $15.4825(4)$ & $15.4365(4)$ \\
\hline$\alpha\left(^{\circ}\right)$ & $112.633(9)$ & $112.9759(12)$ & $112.4815(7)$ & $112.5546(6)$ \\
\hline$\beta\left(^{\circ}\right)$ & $92.380(7)$ & $92.716(7)$ & $92.5320(8)$ & $92.7401(6)$ \\
\hline$\left.x^{\circ}\right)$ & $94.048(9)$ & $94.762(8)$ & $94.8226(7)$ & $94.8365(8)$ \\
\hline$V\left(\AA^{3}\right)$ & 1901.2(3) & 1917.9(3) & $1897.83(8)$ & $1889.23(8)$ \\
\hline$Z$ & 2 & 2 & 2 & 2 \\
\hline$D_{\mathrm{c}}\left(\mathrm{g} \mathrm{cm}^{-3}\right)$ & 1.580 & 1.572 & 1.579 & 1.580 \\
\hline$\mu\left(\mathrm{mm}^{-1}\right)$ & 0.383 & 0.394 & 0.606 & 0.633 \\
\hline$F(000)$ & 934 & 939 & 933 & 926 \\
\hline Goodness-of-fit on $\mathrm{F}^{2}$ & 1.069 & 1.070 & 1.028 & 0.999 \\
\hline Final $R 1, w R_{2}[I>2 \sigma(I)]$ & $0.0635,0.1166$ & $0.0810,0.1449$ & $0.0435,0.1124$ & $0.0356,0.0947$ \\
\hline$R 1, w R_{2}$ (all data) & $0.0961,0.1344$ & $0.1551,0.1702$ & $0.0479,0.1163$ & $0.0392,0.0979$ \\
\hline $\begin{array}{l}\text { Largest diff. peak and } \\
\text { hole }\left(\mathrm{e} \AA^{-3}\right)\end{array}$ & $-0.517,0.823$ & $-0.486,0.478$ & $-0.504,1.814$ & $-0.606,0.748$ \\
\hline
\end{tabular}

were corrected for the diamagnetism of the constituent atoms and the sample holder.

\section{Single-crystal X-ray crystallographic data collection and structure refinement}

5 X-ray diffraction measurements were performed on a Bruker Kappa CCD diffractometer for $\mathbf{2}$ and 3, operating with a $\mathrm{Ag}-\mathrm{K} \alpha$ $(\lambda=0.5608 \AA) \mathrm{X}$-ray tube with a graphite monochromator. For compounds 4 and 5, data were collected at 173(2) K on a Bruker APEX8 CCD Diffractometer equipped with an Oxford ${ }_{10}$ Cryosystem liquid nitrogen device, using graphitemonochromated Mo-K $\alpha(\lambda=0.71073 \AA)$ radiation.

Diffraction data were corrected for absorption and structural determination was achieved using the APEX (1.022) package. The hydrogen atoms were introduced at calculated positions and 15 not refined (riding model). ${ }^{18}$ The structures were solved by direct methods and refined with full-matrix least-squares technique on $F^{2}$ using the SHELXS-97 and SHELXL-97 programs within the WINGX interface. CCDC 888661-888664 contains the supplementary crystallographic data.

\section{${ }_{20}$ Results and Discussion}

\section{Synthesis}

By combining $\left[\mathrm{M}_{1}{ }^{\mathrm{III}}\left(\mathrm{C}_{2} \mathrm{O}_{4}\right)_{3}\right]^{3-}\left(\mathrm{M}_{1}=\mathrm{Fe}\right.$ and $\left.\mathrm{Cr}\right), \mathrm{M}_{2}{ }^{2+}\left(\mathrm{M}_{2}=\mathrm{Co}\right.$, $\mathrm{Fe}$ and $\mathrm{Mn}$ ) with the tosylate salt of the trisamidinium cation (scheme1), a series of six heterotrinuclear complexes of the 25 general formula (TDbenz $)_{2}(\mathrm{TsO})_{2}\left[\mathrm{M}_{2}{ }^{\mathrm{II}}\left(\mathrm{H}_{2} \mathrm{O}\right)_{2}\{(\mu-\right.$ ox) $\left.\left.\mathrm{M}_{1}{ }^{\mathrm{III}}(\mathrm{ox})_{2}\right\}_{2}\right] \cdot 6 \mathrm{H}_{2} \mathrm{O} \cdot 2 \mathrm{CH}_{3} \mathrm{OH}\left(\mathrm{M}_{1}^{\mathrm{III}}=\mathrm{Fe}, \mathrm{M}^{\mathrm{II}}=\mathrm{Mn}(\mathbf{1}), \mathrm{Fe}(2)\right.$, Co (3); $\left.\mathrm{M}^{\mathrm{III}}=\mathrm{Cr} ; \mathrm{M}^{\mathrm{II}}=\mathrm{Mn}(4), \mathrm{Fe}(5), \mathrm{Co}(6)\right)$ have been obtained. Although, TDbenz ${ }^{3+}$ cation has been previously used as $\mathrm{H}$-bond donor unit in solution ${ }^{19}$, in the solid state ${ }^{20}$, gel ${ }^{21}$ and 30 liquid crystal $^{22}$ phases, to the best of our knowledge, it has not been employed as a template for the generation of polynuclear heterometallic species in the solid state. In its unprotonated form, TDbenz, has been also used as a ligand for the formation of coordination compounds. ${ }^{23}$

35 The heterotrinuclear coordination species are of the type
$\left(\mathrm{M}_{1}{ }^{3+}-\mathrm{M}_{2}{ }^{2+}-\mathrm{M}_{1}{ }^{3+}\right)$, the two terminal moieties being $\left[\mathrm{M}_{1}{ }^{\mathrm{III}}(\mathrm{ox})_{3}\right]^{3-}$ $\left(\mathrm{M}_{1}=\mathrm{Fe}, \mathrm{Cr}\right)$ paramagnetic complexes which are robust and stable in solution. The central paramagnetic metal cation $(\mathrm{Fe}, \mathrm{Co}$ and $\mathrm{Mn}$ ) is in the oxidation state II, the most stable in solution under 40 the used conditions.

The synthesis is performed in a 7/2 methanol/water mixture for solubility reasons. In order to increase the solubility of the metallic complex in the solvent mixture, the ammonium salts of the tris(oxalato)metalate(III) are used. It is worth noting that, for 45 other solvents ratio or when starting from the more classical potassium salts, the formation of the trinuclear species was not observed. Despite the complexity of the synthetic mixture composed of five different components $\left(\left(\mathrm{NH}_{4}\right)_{3}\left[\mathrm{M}_{1}{ }^{\mathrm{III}}(\mathrm{ox})_{3}\right] .3 \mathrm{H}_{2} \mathrm{O}\right.$, $\mathrm{M}_{2}{ }^{\mathrm{II}} \mathrm{Cl}_{2} \times \mathrm{xH}_{2} \mathrm{O}$, (TDbenz)(TsO) $)_{3}$ and $7 / 2$ methanol/water mixture), 50 the procedure was fully reproducible and afforded, independently of the nature of the divalent $\left(\mathrm{M}_{2}{ }^{\mathrm{II}}=\mathrm{Mn}, \mathrm{Fe}\right.$ and $\left.\mathrm{Co}\right)$ and trivalent $\left(\mathrm{M}_{1}{ }^{\mathrm{III}}=\mathrm{Fe}\right.$ and $\left.\mathrm{Cr}\right)$ metal ions, a series of isostructural compounds 1-6.

The examples of linear trinuclear species $\left[\mathrm{M}_{2} \mathrm{n}\left(\mathrm{H}_{2} \mathrm{O}\right)_{2}\{(\mu-\right.$

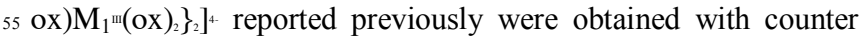
cations possessing a rod-like shape. ${ }^{13-15}$ In contrast, in the present study, the tricationic unit $\mathrm{TDbenz}^{3+}$ (scheme 1) presents a disk-like shape with $C_{3 h}$ symmetry and might form up to $6 \mathrm{H}$-bonds. As previously described for reported compounds mentioned above, 60 the choice of the solvent mixture is one of the important factors allowing to control the solubility as well as the crystallisation kinetics of intermediates and final compounds. As stated above, the prediction of the formation of targeted discrete species with given nuclearity or extended networks with imposed ${ }_{65}$ dimensionality is next to impossible and may only be achieved through empirical strategy based on variation of crystallisation conditions.

The association of a tris(oxalate)metalate(III) entity with a divalent hexaaquametal(II) complexes in solution leads to 70 different equilibria (Scheme 2). The first condensation step is the formation of the binuclear chiral entity $\left[\left(\mathrm{H}_{2} \mathrm{O}\right)_{4} \mathrm{M}_{2}{ }^{\mathrm{II}}(\mu-\right.$ ox $\left.\mathrm{M}_{1}{ }^{\mathrm{III}}(\mathrm{ox})_{2}\right]^{-}$(Scheme 2). ${ }^{24}$ Such species have recently been isolated in the solid state using a H-bond donor dication. ${ }^{12}$ The 
formation of the cis or trans trinuclear entities $\left[\mathrm{M}_{2}{ }^{\mathrm{II}}\left(\mathrm{H}_{2} \mathrm{O}\right)_{2}\{(\mu-\right.$ $\left.\left.\mathrm{ox}) \mathrm{M}_{1}{ }^{\mathrm{III}}(\mathrm{ox})_{2}\right\}_{2}\right]^{4-}$ would then result from the reaction of the binuclear species with a second $\left[\mathrm{M}^{\mathrm{III}}(\mathrm{ox})_{3}\right]^{3-}$ complex.
5 Scheme 2. Schematic representation of the equilibrium in solution between species of increasing nuclearity resulting from the combination of $\left[\mathrm{M}^{\mathrm{III}}(\mathrm{ox})_{3}\right]^{3-}$ with $\left[\mathrm{M}^{\mathrm{II}}\left(\mathrm{OH}_{2}\right)_{6}\right]^{2+}$.

For the trinuclear complex, owing to the chiral nature of the 10 terminal tris(oxalate)metalate complexes ( $\Delta$ and $\Lambda$ enantiomers) and starting from a racemic mixture, one would expect 3 stereoisomers for the trans species whereas, for the cis isomer, 8 stereoisomers can be formed. In the following, the stereochemical issue will not be discussed. The cis isomer has never been 15 isolated so far. This is probably due to the fact that the latter is a precursor of the well-known $3 \mathrm{D}(10,3)$ and $2 \mathrm{D}(6,3)$ extended networks $^{3-10}$ (Scheme 2) and thus is rapidly engaged in polycondensation processes. On the contrary, using much different partners in size, shape and charge (tetrathiafulvalnium, ${ }^{13}$ 20 -stilbazolium ${ }^{14}$ and aminopyridinium ${ }^{15}$ cations and, herein, TDbenz $^{3+}$ trication with $C_{3 h}$ symmetry and tosylate anion), the exclusive formation of the trans- $\left[\mathrm{M}_{2}{ }^{\mathrm{II}}\{(\mu-\right.$ ox $\left.\left.) \mathrm{M}_{1}{ }^{\mathrm{III}}(\mathrm{ox})_{2}\right\}_{2}\left(\mathrm{H}_{2} \mathrm{O}\right)_{2}\right]^{4-}$ isomer in the solid state has been observed for several combinations of metal ions. This indicates 25 the robustness of this heterotrimetallic motif, which may be used as a unit for the generation of higher nuclearity species and extended networks.

\section{Structural description}

All compounds were obtained as crystalline materials. For 2, 3, 4
30 and $\mathbf{5}$, the crystal structure was determined by single crystal Xray diffraction methods. The XRPD analysis of polycrystalline samples revealed that all compounds including $\mathbf{1}$ and $\mathbf{6}$ are isomorphous and present the same diffraction pattern in agreement with the one simulated using the single crystal data for 35 2-5 (Fig. 1).
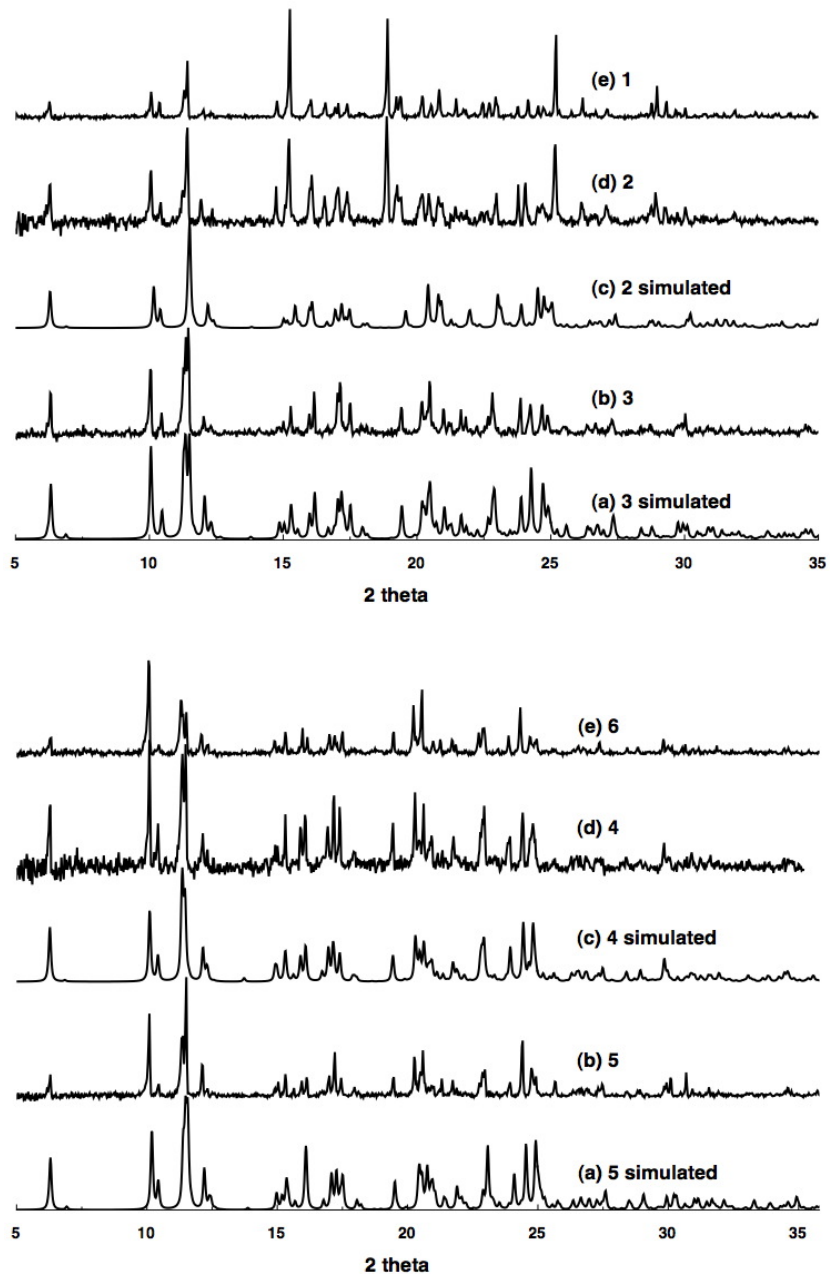

Fig. 1: Comparison of the simulated and observed PXRD patterns. Top: (a) simulated for $\mathbf{3}$ (b) powdered recorded for $\mathbf{3}$ (c) simulated for $\mathbf{2}$ (d) powdered recorded for 2 (e) powdered recorded for 1. Bottom: (a) simulated for 5 (b) powdered recorded for $\mathbf{5}$ (c) simulated for $\mathbf{4}$ (d) powdered recorded for 4 (e) powdered recorded for $\mathbf{6}$. Discrepancies in intensity between the observed and simulated patterns are due to preferential orientations of the microcrystalline powders.

45

Compounds 1-6, of general formula (TDbenz) $)_{2}(\mathrm{TsO})_{2}\left[\mathrm{M}^{\mathrm{II}}\left(\mathrm{H}_{2} \mathrm{O}\right)_{2}\left\{(\mu \text {-ox }) \mathrm{M}^{\mathrm{III}}(\mathrm{ox})_{2}\right\}_{2}\right] \cdot 6 \mathrm{H}_{2} \mathrm{O} 2 \mathrm{CH}_{3} \mathrm{OH}$ $\left(\mathrm{M}^{\mathrm{II}}=\mathrm{Mn}, \mathrm{Fe}\right.$ and $\mathrm{Co}$ and $\mathrm{M}^{\mathrm{III}}=\mathrm{Fe}$ and $\left.\mathrm{Cr}\right)$ crystallize in the $P_{\overline{1}}$ 50 space group. A summary of the crystallographic data is listed in Table 1. In the following, due to their isomorphous character, only the structure of $\mathbf{3}$ will be described in detail.

The asymmetric unit contains half a trimer, one trisamidinium cation, one tosylate anion and solvent molecules in general 55 position (Fig. 2). The cobalt atom, displaying a distorted octahedral geometry, is located on an inversion center and is 
coordinated to four oxygen atoms from two $\left[\mathrm{Fe}(\mathrm{ox})_{3}\right]^{3-}$ units and two water molecules occupying the axial positions. Two types of oxalato ligands (bridging and terminal) are present in the structure. The $\mathrm{Co}-\mathrm{O}_{\text {water }}$ distance is 2.057(5) $\AA$ while the two Co${ }_{5} \mathrm{O}_{\text {oxalate }}$ bond distances are 2.107(4) $\AA$ for Co-O1 and 2.092(4) $\AA$ for $\mathrm{Co}-\mathrm{O} 2$. The presence of the bridging oxalate causes a deformation of the octahedral geometry of both terminal Fe(III) centres. The Fe-O distances are slightly longer for the bridging oxalate (2.023(4) $\AA$ and 2.052(3) $\AA$ ) than for the terminal ligand

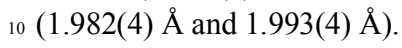

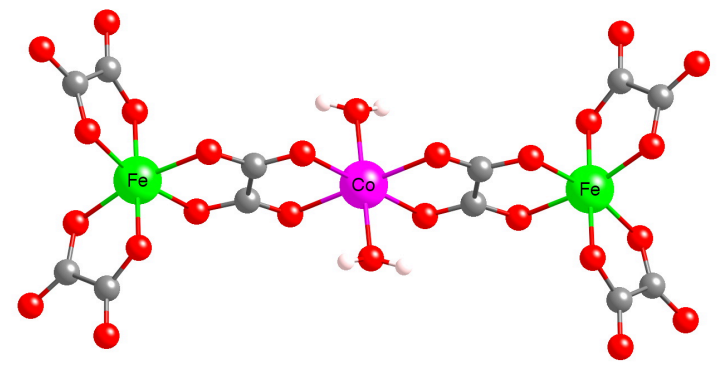

Fig. 2. A portion of the crystal structure of the heterotrinuclear complex 3 (Fe-Co-Fe) showing the bridging of two $\mathrm{Fe}(\mathrm{III})$ and $\mathrm{Co}(\mathrm{II})$ cations by two oxalate units. The same arrangements are observed for 1, 2 and 4-6.

The shortest intramolecular M(III)-M(II) and intermolecular $\mathrm{M}(\mathrm{III})-\mathrm{M}(\mathrm{III})$ distances are $5.418 \AA$ and $11.271 \AA$ respectively for $2,5.452 \AA$ and $10.325 \AA$ for $3,5.407 \AA$ and $12.591 \AA$ for 4 and $5.368 \AA$ and $10.216 \AA$ for $\mathbf{5}$. These values are slightly higher 15 than those observed for analogous oxalate trimeric clusters. ${ }^{13-15}$

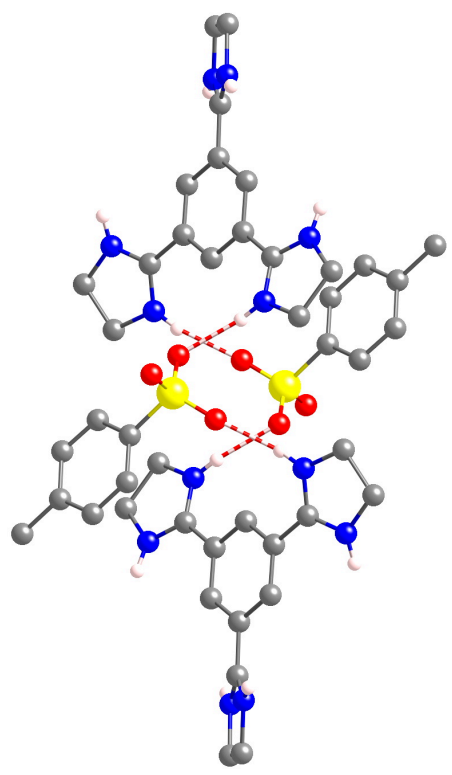

Fig. 3. A portion of the crystal structure of $\mathbf{3}$ showing the $\mathrm{H}$ bonding patterns between the tricationic $\mathrm{Tdbenz}^{3+}$ and monoanionic TsO- counter ions. The same interaction mode is observed for 1, 2 and 4-6.

20 The organic parts of the structure consist of one $\mathrm{TDbenz}^{3+}$ trication and one tosylate anion. The $\mathrm{C}-\mathrm{N}$ bond distances for the cyclic amidinium moiety are in the $1.300(6)-1.313(7) \AA$ range with the N-C-N angles of 112.5(4), 111.9(4) and 112.1(5) ${ }^{\circ}$. The aromatic moiety and the five-membered rings cationic part are 25 not coplanar but tilted by $33.27^{\circ}, 15.88^{\circ}$, and $23.27^{\circ}$. These values are close to those observed for analogous $\mathrm{H}$ bonded networks containing the trisamidinium component. ${ }^{21}$ The cationic and anionic parts behave as $\mathrm{H}$-bond donor and acceptors respectively and form $(2+2)$ dimers, as already observed with 30 amidinium based organic $\mathrm{H}$ bonded networks. ${ }^{24}$ Indeed, they are interconnected through H-bonding interactions between the amidinium $\mathrm{N}$ atoms and the oxygen atoms of the tosylate anion $\left(\mathrm{d}_{\mathrm{N} 3 \cdots \mathrm{O} 15}=2.77 \AA\right.$ and $\left.\mathrm{d}_{\mathrm{N} 6} \cdots \mathrm{O} 13=2.76 \AA\right)$ (Fig. 3 ).

In marked contrast with the other reported trinuclear species, ${ }^{13-15}$ 35 in this series of compounds, the charge neutrality is insured by the simultaneous insertion of both a cation $\left(\right.$ TDbenz $^{3+}$ ) and an anion $\left(\mathrm{TsO}^{-}\right)$. The association of an organic anion with the discrete heterotrinuclear anionic complex in the same solid is unprecedented. It is definitely surprising owing to the 40 electrostatic repulsion between these two species. Nevertheless, as emphasized in Fig. 3, the tosylate anions are involved in a dimeric $\mathrm{H}$ bonded unit, which appears as the effective cationic supramolecular counter-part of the anionic trinuclear complex.

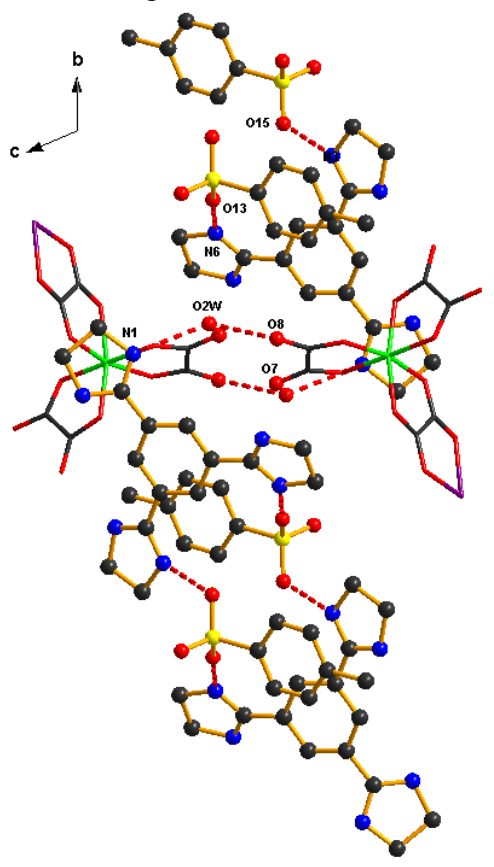

45 Fig. 4. A portion of the structure of the supramolecular zig-zag chains of trimers showing the hydrogen bonding network formed by the alternating assemblies of the trisamidinium cations in the $b c$ plane

The trinuclear complexes form zig-zag type chains along $c$ axis (Fig. 4) through intermolecular hydrogen bonds involving the 50 oxalate oxygen atoms and the lattice water molecules. In the anionic chain, the water molecule $\mathrm{O} 2 \mathrm{w}$ bridges two adjacent trimers through $\mathrm{H}$ bonds to terminal oxalate oxygen atoms $\left(\mathrm{d}_{\mathrm{O} 2 \mathrm{w} \cdots \mathrm{O} 7}=2.83 \AA, \mathrm{d}_{\mathrm{O} 2 \mathrm{w} \cdots \mathrm{O} 8}=2.90 \AA\right)$. The water molecule, coordinated to the central Co atom of one trinuclear complex, is 55 hydrogen bonded to a crystallization water molecule $\left(\mathrm{d}_{\mathrm{O} 1 \mathrm{w} \cdots \mathrm{O} 3 \mathrm{w}}=\right.$ $2.74 \AA$ ) (Fig. 4).

The organic cations form a supramolecular H-bonded network perpendicular to the anionic chains of trimers (Fig. 4). The 
interconnection of the anionic and cationic chains through $\mathrm{H}$ bonds between the water molecule and the oxalate moiety $\left(\mathrm{d}_{\mathrm{O} 2 \mathrm{w} \cdots \mathrm{N} 1}=2.79 \AA\right)$ leads to a $2 \mathrm{D}$ hydrogen-bonded network with alternate arrangements of trisamidinium cations and dimetallic 5 trinuclear units in the $b c$ plane (Fig. 5).

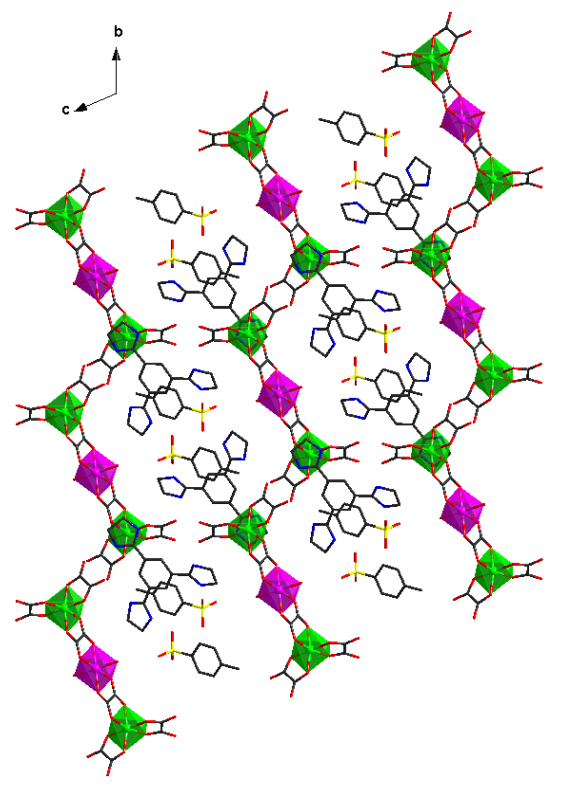

Fig. 5. The packing of $\mathbf{2}$ showing the alternating trimers and trisamidinium cations.

\section{Thermal stability}

${ }_{10}$ The thermal stability of the polycrystalline compounds 1-6 was determined by thermogravimetric analysis (TGA) under nitrogen flow (Fig. 6). The analysis of trinuclear complexes 1-3 revealed that these compounds are stable up to $150{ }^{\circ} \mathrm{C}$, with a first weight loss of $9.3 \%$ for $\mathbf{1}, 9.4 \%$ for $\mathbf{2}$ and $9.2 \%$ for $\mathbf{3}$ between $30-150$ $15{ }^{\circ} \mathrm{C}$ corresponding to the removal of 6 water and 2 methanol solvent molecules (calc.: $9.45 \%, 9.47 \%$ and $9.47 \%$ for $\mathbf{1}, \mathbf{2}$ and $\mathbf{3}$ respectively). Above $160{ }^{\circ} \mathrm{C}$, compounds 1-3 undergo a gradual decomposition.
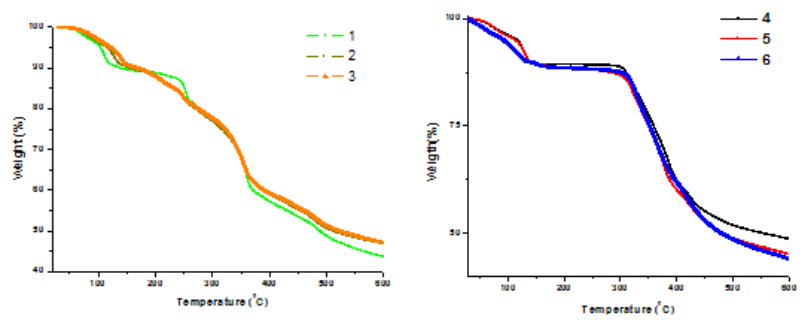

Fig. 6: TGA traces for compounds 1-6

In marked contrast, the thermal analysis performed on 25 compounds 4-6 revealed a thermal stability up to $300{ }^{\circ} \mathrm{C}$. The first weight loss of $10.9 \%$ for $\mathbf{4}, 11.5 \%$ for 5 and $11.2 \%$ for $\mathbf{6}$ taking place between $30-200{ }^{\circ} \mathrm{C}$ corresponds to the removal of 8 water molecules ( 6 crystallisation molecules and 2 coordinated to $\mathrm{M}^{\mathrm{II}}$ ions) and 2 methanol molecules (calc.: $11.5 \%, 11.49 \%$ and
$3011.47 \%$ for $\mathbf{4}, 5$ and 6 respectively). Above $300{ }^{\circ} \mathrm{C}$, compounds 4-6 decompose rather rapidly.

The higher thermal stability of compounds 4-6 compared to compounds 1-3 is in agreement with the inertness of the chromium(III) octahedral complexes compared to their iron(III)

35 analogues. In contrast, for a given peripheral atom, the nature of the central metal(II) ion only slightly influences the thermal stability of the complex.

\section{Magnetic Properties}

The $d c$ magnetic properties of 1-6 have been investigated in the ${ }_{40} 2-300 \mathrm{~K}$ temperature range. The thermal variations of the $\chi_{\mathrm{M}} T$ product, $\chi_{\mathrm{M}}$ being the molar magnetic susceptibility per trinuclear unit, are shown in Fig. 7 and 8.

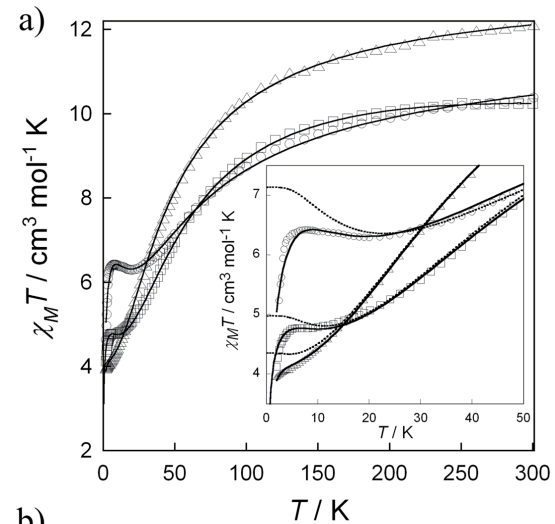

b)

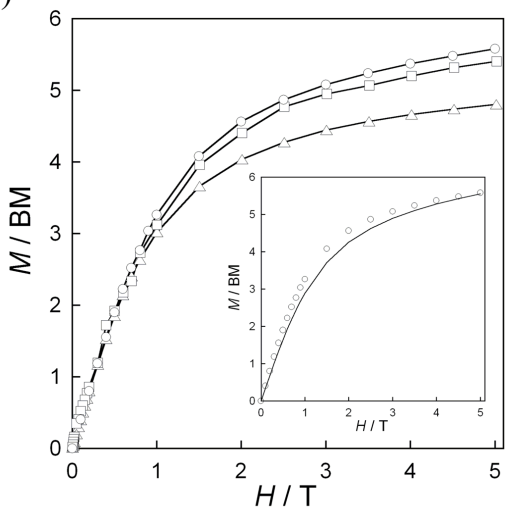

Fig. 7. (a) Temperature dependence of $\chi_{M} T$ of $1(\Delta), 2$ ( $\square$ ) and 3 (०). The 45 inset emphasizes the low temperature behaviour. The solid lines are the best-fitted curves (see text). The dotted lines in the inset are the theoretical curves showing the magnetic behaviour of 1-3 in the absence of intermolecular interactions. (b) Field dependence of the magnetization $(M)$ of $\mathbf{1}(\Delta), 2(\square)$ and $\mathbf{3}(\circ)$ at $T=2.0 \mathrm{~K}$. The solid lines are presented as 50 eye-guides. The solid line in the inset shows the simulation of the experimental data for the compound $\mathbf{3}$ using the same fit parameters obtained from the fit of the magnetic susceptibility (VPMAG package).

For compounds 1-3 (Fig. 7), the $\chi_{\mathrm{M}} T$ values at room 55 temperature $\left[12.03(\mathbf{1}), 10.23(2)\right.$ and $\left.10.33 \mathrm{~cm}^{3} \mathrm{~mol}^{-1} \mathrm{~K}(3)\right]$ are slightly below those expected for the sum of the corresponding three non-interacting magnetic centres [Fe $\mathrm{Fe}^{\mathrm{III}}: \chi_{\mathrm{M}} T=4.37 \mathrm{~cm}^{3} \mathrm{~K}$ $\mathrm{mol}^{-1}$ with $S=5 / 2$ and $\mathrm{g}=2.0 ; \mathrm{Mn}^{\mathrm{II}}: \chi_{\mathrm{M}} T=4.37 \mathrm{~cm}^{3} \mathrm{~K} \mathrm{~mol}^{-1}$ with $S=5 / 2$ and $\mathrm{g}=2.0 ; \mathrm{Fe}^{\mathrm{II}}: \chi_{\mathrm{M}} T=3.63 \mathrm{~cm}^{3} \mathrm{~K} \mathrm{~mol}^{-1}$ with $S=2$ 60 and $\mathrm{g}=2.2 ; \mathrm{Co}^{\mathrm{II}}: \chi_{\mathrm{M}} T=2.48 \mathrm{~cm}^{3} \mathrm{~K} \mathrm{~mol}^{-1}$ with $S=3 / 2$ and $\mathrm{g}=$ 
2.3]. For 1, the $\chi_{\mathrm{M}} T$ value decreases monotonically as the temperature is lowered. Nevertheless, the evolution of the decreasing rate is not monotonic: it increases down to $20 \mathrm{~K}$, then it decreases between $20 \mathrm{~K}$ and $5 \mathrm{~K}$ before increasing sharply at 5 low temperature. For $\mathbf{2}$, the evolution is similar except that the decreasing rate reaches zero between $8 \mathrm{~K}$ and $5 \mathrm{~K}$ with a $\chi_{\mathrm{M}} T$ value of $4.77 \mathrm{~cm}^{3} \mathrm{~mol}^{-1} \mathrm{~K}$ before increasing again at low temperature. Finally, for $\mathbf{3}$, the $\chi_{\mathrm{M}} T$ product exhibits a rounded minimum of $6.33 \mathrm{~cm}^{3} \mathrm{~mol}^{-1} \mathrm{~K}$ at $22 \mathrm{~K}$ then increases slightly to 10 reach $6.42 \mathrm{~cm}^{3} \mathrm{~mol}^{-1} \mathrm{~K}$ at $5.0 \mathrm{~K}$ and then steeply decreases at low temperature.

In all three cases, the initial decrease of the $\chi_{\mathrm{M}} T$ product is the signature of the antiferromagnetic exchange interaction between the metal(II) ion and the terminal iron(III) centres through the 15 oxalate bridge. This is in line with the low value of the $\chi_{\mathrm{M}} T$ product at room temperature. The spin structure resulting from such an interaction is said to be irregular because the energy of the low-lying states does not vary monotonically with its spin value. ${ }^{25}$ As a direct consequence of these irregular spin structures, 20 a minimum of the $\chi_{\mathrm{M}} T$ product is expected when the temperature is lowered before it increases again towards the value expected when only the ground state is populated (inset of Fig. 7a). In the case of $\mathbf{3}$, this minimum is clearly seen but the expected increase at low temperature remains modest because of (i) the moderate 25 value of the exchange interaction and (ii) the occurrence of zerofield splitting (ZFS) and/or intermolecular antiferromagnetic interactions which induce the observed decrease at low temperature. For $\mathbf{1}$ and 2, these latter phenomena prevent the observation of the expected minima.

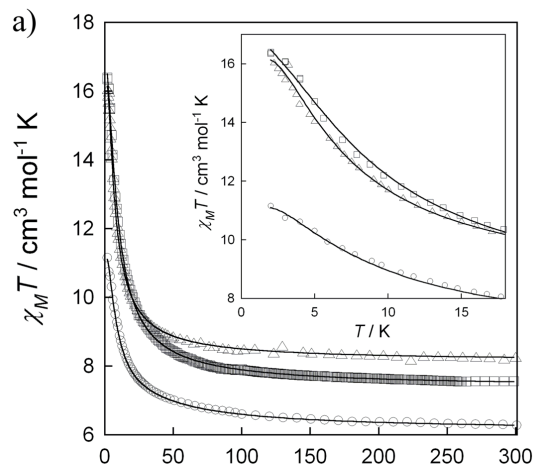

b)

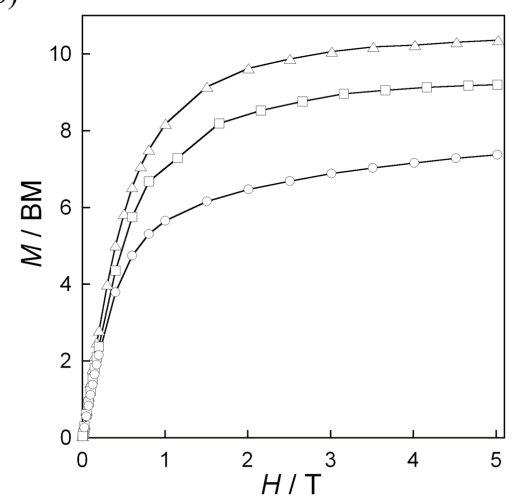

30

Fig. 8. (a) Temperature dependence of $\chi_{\mathrm{M}} T$ of $4(\Delta), 5$ ( $\square$ ) and 6 (०). The inset emphasizes the low temperature behaviour. The solid lines are the best-fitted curves (see text). (b) Field dependence of the magnetization
$(M)$ of $4(\Delta), 5(\square)$ and $6(\circ)$ at $T=2.0 \mathrm{~K}$. The solid lines are only eye35 guides

For compounds 4-6 (Fig. 8), the thermal evolution of the $\chi_{\mathrm{M}} T$ is much simpler. At room temperature, the $\chi_{\mathrm{M}} T$ values [8.26 (4), $7.56(5)$ and $\left.6.28 \mathrm{~cm}^{3} \mathrm{~mol}^{-1} \mathrm{~K}(6)\right]$ are rather close however slightly above those expected for the sum of the corresponding 40 non-interacting metal atoms $\left[\mathrm{Cr}^{\mathrm{III}}: \chi_{\mathrm{M}} T=1.87 \mathrm{~cm}^{3} \mathrm{~K} \mathrm{~mol}^{-1}\right.$ with $S=3 / 2$ and $\mathrm{g}=2.0]$. Upon cooling, $\chi_{\mathrm{M}} T$ of 4-6 increases continuously to reach values of $16.06(4), 15.51$ (5) and 11.15 (6) $\mathrm{cm}^{3} \mathrm{~mol}^{-1} \mathrm{~K}$ at $2.0 \mathrm{~K}$. These observations are indicative of a ferromagnetic exchange interaction between the metal(II) ion and 45 the terminal chromium(III) centres through the oxalate bridge. The values reached at $2 \mathrm{~K}$ are below those expected for $S=11 / 2$ (4), 5 (5) and $9 / 2$ (6) ground states resulting from the intramolecular ferromagnetic coupling between two $\mathrm{Cr}^{\mathrm{III}}$ ions and the corresponding high spin $\mathrm{M}^{\mathrm{II}}$ ion within the $\mathrm{Cr}_{2}^{\mathrm{III}}{ }_{2} \mathrm{M}^{\mathrm{II}}$ linear 50 triad. This indicates that some low spin excited states with are still populated at this temperature because the exchange interaction is relatively modest for these compounds.

The $M$ versus $H$ plots for 1-3 and 4-6 at $2.0 \mathrm{~K}, M$ being the molar magnetization per trinuclear unit, are shown in Fig. $7 \mathrm{~b}$ and $558 \mathrm{~b}$ respectively. The magnetization values for 1-6 are consistent with those expected for antiferromagnetic $[M($ at $5 \mathrm{~T})=4.8(\mathbf{1})$, 5.4 (2) and $5.6(3) N \beta]$ or ferromagnetic $[M($ at $5 \mathrm{~T})=10.3(4)$, 9.2 (5) and 7.3 (6) $N \beta$ ] exchange interaction between the metal ions in the corresponding trinuclear compound. ${ }_{60}$ Les paramètres requis sont manquants ou erronés.

Les paramètres requis sont manquants ou erronés.

To quantify these observations, the analysis of the magnetic susceptibility data of compounds 1, 2, 4 and 5 was carried out by full-matrix diagonalization ${ }^{26}$ of the isotropic spin Hamiltonian for 65 a trinuclear model by using eq. (1):

$$
\begin{aligned}
\mathbf{H}= & -J\left(\mathbf{S}_{\mathrm{M}^{\mathrm{II}}} \cdot \mathbf{S}_{\mathrm{M} 1^{\mathrm{II}}}+\mathbf{S}_{\mathrm{M}^{\mathrm{II}}} \cdot \mathbf{S}_{\mathrm{M}^{\mathrm{m}}}\right)+z j<\mathbf{S}_{\mathbf{z}}>\mathbf{S}_{\mathbf{z}} \\
& +g_{\mathrm{M}^{\mathrm{II}}} \mathbf{S}_{\mathrm{M}^{\mathrm{II}}} B+g_{\mathrm{M}^{\mathrm{m}}}\left(\mathbf{S}_{\mathrm{M} 1^{\mathrm{II}}}+\mathbf{S}_{\mathrm{M} 2^{\mathrm{II}}}\right) B
\end{aligned}
$$

where $J$ and $z j$ are the intra- and intermolecular magnetic coupling parameters respectively, and $g_{\mathrm{M}^{\mathrm{I}}}$ and $g_{\mathrm{M}}{ }^{\mathrm{m}}$ are the Landé 70 factors of the $\mathrm{Mn}^{\mathrm{II}}$ and $\mathrm{Cr}^{\mathrm{III}}$ ions. The $z j$ takes into account weak intermolecular interactions within the mean field approximation. It can be set to zero to simulate the magnetic behaviour of an isolated heterotrinuclear complex (insert of Fig. 7a).

The least-squares fit parameters of the experimental data are 75 given in Table 2 . The fitted curves closely follow the experimental data of $\mathbf{1}, \mathbf{2}, \mathbf{4}$ and $\mathbf{5}$ in the whole temperature range. (Fig. 7a and 8a).

The fit of the magnetic data by using eq. (1) gave poor results for 3 and 6. So, in order to take into account the local axial zero 80 field splitting (ZFS) of the cobalt(II) ion $^{27}$ in these compounds, the following Hamiltonian was used:

$$
\begin{aligned}
\mathbf{H}= & -J\left(\mathbf{S}_{\mathrm{Co}} \cdot \mathbf{S}_{\mathrm{M} 1^{\mathrm{II}}}+\mathbf{S}_{\mathrm{Co}} \cdot \mathbf{S}_{\mathrm{M} 2^{\mathrm{II}}}\right)+D_{\mathrm{Co}} \mathbf{S}_{\mathbf{z C o}}{ }^{2} \\
& +g_{\mathrm{Co}} \mathbf{S}_{\mathrm{Co}} B+g_{\mathrm{M}^{\mathrm{II}}}\left(\mathbf{S}_{\mathrm{M} 1^{\mathrm{II}}}+\mathbf{S}_{\mathrm{M} 2^{\mathrm{II}}}\right) B
\end{aligned}
$$

where $J$ is the intramolecular magnetic coupling parameter, $D_{\text {Co }}$ is the axial magnetic anisotropy parameter of the $\mathrm{Co}^{\mathrm{II}}$ ion, and $g_{\mathrm{Co}}$ and $g_{\mathrm{M}^{\mathrm{II}}}$ are the Landé factors of the $\mathrm{Co}^{\mathrm{II}}$ and $\mathrm{M}^{\mathrm{III}}$ ions, 85 respectively. This Hamiltonian does not include the intermolecular interactions because both parameters, $z j$ and $D_{\mathrm{Co}}$ are strongly correlated leading to a possible overparametrization 
of the system. Thus, the calculated $D_{\text {Co }}$ value should be considered as an upper limit. In order to further verify these $D_{\text {Co }}$ values, we reproduced the $M v s$. $H$ behaviour for $\mathbf{3}$, using the VPMAG package, ${ }^{26}$ with the same fit parameters obtained from 5 the fit of the magnetic susceptibility (inset of Figure $7 b$ ).

For all compounds, the fitted curve matches the experimental data in the whole temperature range (Fig. 7a and 8a). The parameters extracted from the fit of the experimental data are gathered in Table 2. The fits were carried out in both cases 10 keeping fixed $\mathrm{g}\left(\mathrm{Fe}^{\mathrm{m}}\right)=2.00(\mathbf{1}, \mathbf{2}$ and $\mathbf{3})$ and $\mathrm{g}\left(\mathrm{Cr}^{\mathrm{m}}\right)=2.00(\mathbf{4}, \mathbf{5}$ and 6).

Table 2: Best-fit magnetic parameters for compounds 1-6

\begin{tabular}{cccccccc} 
compound & fit & $J^{a} / \mathrm{cm}^{-1}$ & $\theta^{b} / \mathrm{K}$ & $D^{c} / \mathrm{cm}^{-1}$ & $g_{\mathrm{M}^{11}}{ }^{d}$ & $g_{\mathrm{M}^{\mathrm{II}}}{ }^{d}$ & $R^{e}\left(\times 10^{5}\right)$ \\
\hline $\mathbf{1}$ & 1 & -4.23 & -0.25 & - & 2.00 & 2.00 & 2.9 \\
$\mathbf{2}$ & 1 & -6.73 & -0.32 & - & 2.32 & 2.00 & 3.2 \\
$\mathbf{3}$ & 2 & -8.97 & - & 29.3 & 2.30 & 2.00 & 5.1 \\
$\mathbf{4}$ & 1 & +1.21 & -0.14 & - & 2.00 & 2.00 & 6.9 \\
$\mathbf{5}$ & 1 & +2.20 & 0.057 & - & 2.18 & 2.00 & 2.3 \\
$\mathbf{6}$ & 2 & +3.63 & - & 27.44 & 2.22 & 2.00 & 5.7
\end{tabular}

${ }^{a}$ Intramolecular magnetic exchange coupling. ${ }^{b} \theta$ is the Weiss factor 15 defined as $\theta=z j S(S+1) / 3 k .{ }^{c}$ Axial magnetic anisotropy parameter. ${ }^{d}$ Landé factors. $e$ Agreement factor $R=\sum\left[\left(\chi_{M} T\right)_{\exp }\right.$ $\underline{\left.\left(\chi_{M} T\right)_{\text {calcd }}\right]^{2} / \sum\left[\left(\chi_{M} T\right)_{\exp }\right]^{2}}$

The nature and amplitude of the exchange interaction found in 20 compounds 1-6 is comparable to those found in the previously described dinuclear and trinuclear complexes. ${ }^{11-15}$ It thus appears that the coordination environment of each metal ion and the geometry of the bridging ligand have a stronger influence on the exchange interaction than the overall symmetry of the cluster.

25 This statement underlines the local nature of the phenomena that drive the exchange interaction in these systems.

The large and positive $D$ values observed for the cobalt(II) derivatives $\mathbf{3}$ and $\mathbf{6}$ are comparable to the values reported for other cobalt(II) complexes $^{28}$ but significantly higher than those 30 previously published for a trinuclear complex for which this parameter was evaluated. ${ }^{15}$ In any case, this value has to be considered as an upper limit. The crystal structures of the three trinuclear compounds show an important tetragonal distortion from the ideal octahedral geometry. This breaks the degeneracy ${ }_{35}$ of the triplet orbital state ${ }^{4} \mathrm{~T}_{1 \mathrm{~g}}$ into ${ }^{4} \mathrm{E}_{\mathrm{g}}$ and ${ }^{4} \mathrm{~A}_{2 \mathrm{~g}}$ decreasing the orbital contributions. ${ }^{29}$ The difference in magnitude for the $D$ value observed between complexes $\mathbf{3}$ and $\mathbf{6}$ and the previously reported one ${ }^{15}$ cannot be solely attributed to the slightly different distortion observed in this latter case since, as shown using the 40 angular overlap model (AOM), ${ }^{28 a}$ subtle angular modifications of the cobalt(II) environment can strongly influence the value of $D$ as well.

Finally, despite the recent publication of the first examples of mononuclear cobalt(II) single-molecule magnets (SMMs) 45 exhibiting positive $D$ values, ${ }^{28 b, 30}$ we did not observed slow magnetic relaxation effects typical of SMMs for compounds 3 and 6. However, the high absolute value of $D$ may be used to design new SMMs in properly engineered systems. ${ }^{31}$

\section{Conclusions}

50 In this contribution, we have shown that combining $\left[\mathrm{M}^{\mathrm{III}}(\mathrm{Ox})_{3}\right]^{3-}$ $\left(\mathrm{M}=\mathrm{Fe}\right.$ and $\mathrm{Cr}$ ) building blocks, $\left[\mathrm{M}^{\mathrm{II}}\left(\mathrm{H}_{2} \mathrm{O}\right)_{\mathrm{x}}\right]^{2+}(\mathrm{M}=\mathrm{Fe}, \mathrm{Co}$ and
Mn) labile complexes, $C_{3 h}$ shaped tricationic unit and tosylate anion in a water/methanol mixture leads to the formation of a series of 6 isostructural heterotrinuclear complexes. For these 55 compounds, the linear trans-trinuclear complexes are associated with the H-bonded disk-shape cation and a tosylate anion. The linear trinuclear complexes may be used as starting species for the design and formation of higher nuclearity complexes or extended networks. Work along these lines are currently under 60 investigation.

In addition, the magnetic coupling between the two trivalent metal ions and the high spin $\mathrm{Mn}$ (II), $\mathrm{Fe}$ (II) and $\mathrm{Co}(\mathrm{II})$ ions across the oxalate bridges leads to large spin ground states, which, together with the large magnetic anisotropy of some of these 65 metal ions, opens the possibility for observing slow magnetic relaxation effects typical of SMMs in this type of compounds as previously described only in one other oxalate-bridged system. ${ }^{32}$

\section{Acknowledgement}

This work was supported by the Centre National de la Recherche ${ }_{70}$ Scientifique (CNRS), Université de Strasbourg (UdS), Université Joseph Fourier (UJF), Institut Universitaire de France (IUF) and the Agence Nationale de la Recherche (ANR) within the framework of the ANR-08-JCJC-0113-01 project in particular through a postdoctoral grant to $\mathrm{CM}$.

\section{${ }_{75}$ Notes and references}

${ }^{a}$ Laboratoire National des Champs Magnétiques Intenses, UPR CNRS 3228, 25 rue des Martyrs, B.P. 166, 38042 Grenoble cedex 9, France

${ }^{b}$ Inorganic Chemistry Laboratory, Faculty of Chemistry, University of Bucharest, Str. Dumbrava Rosie nr. 23, 020464 Bucharest, Romania

$80{ }^{c}$ Departament de Química Inorgànica, Instituto de Ciencia Molecular (ICMOL). Universitat de València. 46980 Paterna, València, Spain

${ }^{d}$ Laboratoire de Chimie de Coordination Organique, UMR CNRS-UdS 7140, Université de Strasbourg, Institut Le Bel, 4, rue Blaise Pascal, F67000 Strasbourg, France

$85{ }^{e}$ Institut Universitaire de France (IUF)

${ }^{f}$ Université Joseph Fourier, BP 53, F-38041 Grenoble Cedex 9, France

\section{$\dagger$ Electronic Supplementary Information (ESI) available:}

Crystallographic data (excluding structure factors) for 2, 3, 4 and 5 have been deposited with the Cambridge Crystallographic Data Centre, as 90 CCDC-888661-888664. Copies of the data may be obtained free of charge on application to The Director, CCDC, 12 Union Road, Cambridge CB2 1EZ, UK (fax: +44 $1223 \quad 336$ 033; e-mail: deposit@.ccdc.cam.ac.uk or www: http://www.ccdc.cam.ac.uk). See DOI: $10.1039 / \mathrm{b} 000000 \mathrm{x}$

1 (a) O. Kahn, Struct. Bond. (Berlin), 1987, 68, 89; (b) Y. Pei, Y. Journaux, O. Kahn, Inorg. Chem. 1988, 27, 399-404. (c) O. Kahn, Adv. Inorg. Chem.1995, 43, 179 ; (d) M. Pilkington, S. Decurtins, J.S. in, M. Miller, Drillon (Eds.), Magnetism: Molecules to Materials II, VCH, Weinheim, 2001, 339; (d) G. Marinescu, M. Andruh, F. Lloret and M. Julve, Coord. Chem. Rev., 2011, 255, 161.

2 (a) O. Kahn, Acc. Chem. Res., 2000, 33, 647; (b) S. Kitagawa, S. Noro and T. Nakamura, Chem. Commun., 2006, 701; (c) M. Andruh, Chem. Commun., 2007, 2565; (d) E. Pardo, R. Ruiz-Garcia, J. Cano, X. Ottenwaelder, R. Lescouëzec, Y. Journaux, F. Lloret and M. Julve, Dalton Trans., 2008, 2780; (e) E. C. Constable, Coord. Chem. Rev., 2008, 252, 842; (f) S. J. Garibay, J. R. Stork and S. M. Cohen, Prog. Inorg. Chem., 2009, 56, 335; (h) M. Andruh, Chem. Commun., 2011, 47, 3025 .

3 (a) S. Decurtins, H. W. Schmalle, P. Schneuwly, H. R. Oswald, Inorg. Chem. 1993, 32, 1888; (b) S. Decurtins, H. W. Schmalle, P. 
Schneuwly, J. Ensling, P. Gütlich, J. Am. Chem. Soc. 1994, 116, 9521; (c) M. Hernández-Molina, F. Lloret, C. Ruiz-Pérez, M. Julve, Inorg. Chem. 1998, 37, 4141; (d) M. Gruselle, R. Andrés, B. Malézieux, M. Brissard, C. Train, M. Verdaguer, Chirality, 2001, 13, 712; (e) E. Coronado, J. R. Galán-Mascarós, C. J. Gómez- García, J. M. Martínez-Agudo, Inorg. Chem. 2001, 40, 113; (f) M. ClementeLeón, E. Coronado, C. J. Gómez-García and A. Soriano-Portillo, Inorg. Chem., 2006, 45, 5653; (g) F. Pointillart, C. Train, F. Villain, C. Cartier dit Moulin, P. Gredin, L.-M. Chamoreau, M. Gruselle, G. Aullon, S. Alvarez, M. Verdaguer, J. Am. Chem. Soc., 2007, 129, 1327.

4 (a) M. Clemente-León, E. Coronado, M. C. Giménez-López, A. Soriano-Portillo, J. C Waerenborgh, F. Delgado, C. Ruiz-Pérez Inorg. Chem. 2008, 47, 9111; (b) M. Clemente-León, E. Coronado, M. López-Jordà, G. Mínguez Espallargas, A. Soriano-Portillo and J. C Waerenborgh Chem. Eur. J. 2010, 16, 2207 ; (c) M. Clemente-León, E. Coronado, M. López-Jordà, Dalton Trans., 2010, 39, 4903.

5 (a) M. Clemente-León, J. R. Galán-Mascarós, C. J. Gómez-García, Chem. Commun. 1997, 1727; (b) E. Coronado, J. R. Galán-Mascarós, C. J. Gómez-García, J. M. Martínez-Agudo, Adv. Mater. 1999, 11, 558; (c) E. Coronado, J. R. Galán-Mascarós, C. J. Gómez-García, J. Ensling, P. Gutlich, Chem. Eur. J. 2000, 6, 552.

6 E. Coronado, C. Giménez-Saiz, C. J. Gómez-Garcia, F. M. Romero, A. Tarazón, J. Mater. Chem. 2008, 18, 929.

7 (a) S. Bénard, P. Yu, J. P. Audière, E. Rivière, R. Clèment, J. Ghilhem, L. Tchertanov, K. Nakatami, J. Am. Chem. Soc. 2000, 122, 9444; (b) S. M. Aldoshin, N. A. Sanina, V. I. Minkin, N. A. Voloshin, V. N. Ikorskii, V. I. Ovcharenko, V. A. Smirnov, N. K. Nagaeva, J. Mol. Struct. 2007, 826, 69.

8 (a) S. Bénard, E. Rivière, P. Yu, K. Nakatami, J. F. Delouis, Chem. Mater. 2001, 13, 159; (b) M. Gruselle, B. Malézieux, S. Bénard, C. Train, C. Guyard-Duhayon, P. Gredin, K. Tonsuaadu, R. Clément, Tetrahedron Assym., 2004, 15, 3103; (d) E. Pardo, C. Train, H. Liu, L. M. Chamoreau, B. Dkhil, K. Boubekeur, F. Lloret, K. Nakatani, H. Tokoro, S. Ohkoshi, M. Verdaguer, Angew. Chem. Int. Ed. Engl., $2012, \mathbf{5 1}, 8356$.

9 (a) M. Kurmoo, A. W. Graham, P. Day, S. J. Coles, M. Hursthouse, J. L. Caulfield, J. Singleton, F. L. Pratt, W. Hayes, L. Ducasse, P. Guionneau, J. Am. Chem. Soc. 1995, 117, 12209; (b) E. Coronado, J. R. Galán-Mascarós, C. J. Gómez-García V. Laukhin, Nature 2000, 408, 447; (c) A. Alberola, E. Coronado, J. R. Galán-Mascarós, C. Giménez-Saiz, C. J. Gómez-García, J. Am. Chem. Soc., 2003, 125, 10774.

10 (a) C. Train, R. Gheorghe, V. Krstic, L.-M. Chamoreau, N.S. Ovanesyan, G. L. J. A. Rikken, M. Gruselle, M. Verdaguer, Nat. Mater., 2008, 7, 729; (b) M. Clemente-León, E. Coronado, J. C. Dias, A. Soriano-Portillo, R. D. Willett, Inorg. Chem. 2008, 47, 6458; (c) C. Train, T. Nuida, R. Gheorghe, M. Gruselle, S.-I. Ohkoshi, J. Am. Chem. Soc. 2009, 131, 16838.

11 (a) M. Ohba, H. Tamaki, N. Matsumoto and H. Okawa, Inorg. Chem., 1993, 32, 5385; (b) R. Lescouëzec, G. Marinescu, J. Vaissermann, F. Lloret, J. Faus, M. Andruh and M. Julve, Inorg. Chim. Acta, 2003, 350, 131; (c) G. Marinescu, D. Visinescu, A. Cucos, M. Andruh, Y. Journaux, V. Kravtsov, Yu.A. Simonov and J. Lipkowski, Eur. J.
Inorg. Chem. 2004, 2914; (d) S. Nastase, F. Tuna, C. Maxim, C.A. Muryn, N. Avarvari, R.E.P. Winpenny and M. Andruh, Cryst. Growth Des., 2007, 7, 1825; (e) S. Nastase, C. Maxim, F. Tuna, C. Duhayon, J-P. Sutter, M. Andruh Polyhedron, 2009, 28, 1688.

12 C. Maxim, S. Ferlay, C. Train New.J. Chem., 2011, 35, 1254.

13 (a) E. Coronado, J. R. Galán-Mascarós, C. Giménez-Saiz, C. J. Gómez-García, C. Ruiz-Pérez and S. Triki, Adv. Mater., 1996, 8, 737; (b) E. Coronado, J. R. Galán-Mascarós, C. Giménez-Saiz, C. J. Gómez-García and C. Ruiz-Pérez, Eur. J. Inorg. Chem., 2003, 2290.

14 Y-Q. Sun, J. Zhang, G-Y. Yang, Dalton Trans., 2006, 1685.

15 E. Pardo, C. Train, R. Lescouëzec, K. Boubekeur, E. Ruiz, F. Lloret and M. Verdaguer, Dalton Trans., 2010, 39, 4951.

16 J. C. Bailar and E. M. Jones, Inorg. Synth., 1939, 1, 37.

17 A. Kraft and R. Frohlich, Chem. Commun., 1998, 1085.

18 G. M. Sheldrick, Programs for the Refinement of Crystal Structures, University of Göttingen, Göttingen, Germany, 1996.

19 A. Kraft and A. Reichert Tetrahedron, 1999, 55, 3923.

T. Grawe, T. Schrader, R. Zadmard and A. Kraft J. Org. Chem. 2002, 67, 3755.

20 (a) A. Kraft and R. Fröhlich Chem. Commun., 1998 1085; (b) A. Kraft J. Chem. Soc., Perkin Trans., 1999, 1, 705; (c) A. Kraft, F. Osterod and R. Fröhlich J. Org. Chem. 1999, 64, 6425; (d) F. Osterod, L. Peters, A. Kraft, T. Sano, J. J. Morrison, N. Feederc and A. B. Holmes J. Mater. Chem., 2001, 11, 1625; (e) H-J. Kim, S. Sakamoto, K. Yamaguchi J-I. Hong Org. Lett., 2003, 5, 1051; (f) H. Y. Lee, D. Moon, M. S. Lah, and J-I. Hong, J. Org. Chem. 2006, 71, 9225; (g) H. Y. Lee, H-J. Kim, K. J. Lee, M. S. Lah and J-I. Hong CrystEngComm, 2007, 9, 78.

21 (a) A. Kraft, and F. Osterod J. Chem. Soc., Perkin Trans., 1999, 1, 1019; (b) S. R. Nam, H. Y. Lee, J-I. Hong Tetrahedron, 2008, 64, 10531.

22 A. Kraft, A. Reichert and R. Kleppinger Chem. Commun., 2000, 1015

23 (a) M. Dinca, A. Dailly, Y. Liu, C. M. Brown, D.. A. Neumann and J. R. Long J. Am. Chem. Soc., 2006, 128, 16876; (b) H. Yang, J-M. Chen, J-J. Sun, S-P. Yang, J. Yu, H. Tanb and W. Li Dalton Trans., $2009,2540$.

24 a) O. Félix, PhD thesis, Université Louis Pasteur, Strasbourg, 1999 ; (b) M. W. Hosseini. Acc. Chem. Res., 2005, 38, 313.

25 Y. Pei, Y. Journaux, O. Kahn, Inorg. Chem. 1988, 27, 399.

26 J. Cano, VPMAG package; University of Valencia, Valencia, Spain, 2003.

27 F. Lloret, M. Julve, J. Cano, R. Ruiz-García, E. Pardo, Inorg. Chim. Acta 2008, 361, 3432.

28 (a) R. Boca, Coord. Chem. Rev., 2004, 248, 757. (b) Julia Vallejo, I. Castro, R. Ruiz-García, J. Cano, M. Julve, F. Lloret, G. De Munno, W. Wernsdorfer, E. Pardo, J. Am. Chem. Soc. 2012, 134, 15704.

29 L. Banci, A. Bencini, C. Benelli, D. Gatteschi, C. Zanchini, Struct. Bonding (Berlin), 1982, 52, 37.

30 J. M. Zadrozny, J.Liu, N. A. Piro, C. J. Chang, S. Hill, J. R. Long, Chem. Commun., 2012, 48, 3927.

31 E. Tancini, M. J. Rodriguez-Douton, L. Sorace, A.-L. Barra, R. Sessoli, A. Cornia, Chem. Eur.J., 2010, 16, 10482.

32 J. Martínez-Lillo, D. Armentano, G. De Munno, W. Wernsdorfer, M. Julve, F. Lloret and J. Faus, J. Am. Chem. Soc., 2006, 128, 14218. 